This is a post-print version of: Wyatt, M. (2010). An English teacher's developing self-efficacy beliefs in using groupwork. System 38 (4), 603-613. http://www.sciencedirect.com/science/article/pii/S0346251X10001120

\title{
An English teacher's developing self-efficacy beliefs in using groupwork
}

\author{
By Mark Wyatt \\ University of Portsmouth
}

\begin{abstract}
In this article, I explore how an English teacher's self-efficacy beliefs in using groupwork developed, specifically with regard to his work with young learners, while he was engaged part-time on an in-service BA TESOL programme in the Middle East. Using qualitative case study methodology, I uncover various aspects of his self-efficacy growth, highlighting links between this and growth in his practical knowledge relating to the learners and learning, the curriculum, teaching techniques, the school context and his own sense of himself as a researcher of his own practice. Results indicate that, throughout the three-year programme, there was unevenness in growth across these various dimensions of practical knowledge, which appeared to influence the teacher's developing self-efficacy in using groupwork in various ways. After exploring possible reasons for this, I discuss implications.
\end{abstract}

Key words: teachers' self-efficacy, practical knowledge, groupwork, constructivist teacher education

\section{Teachers' self-efficacy and practical knowledge}

Teachers' self-efficacy (TSE) beliefs, which I define as their beliefs in their abilities to support learning in various task and context-specific cognitive, metacognitive, affective and social ways, have been researched by educational psychologists and teacher educators since the pioneering work of Bandura (1977). According to Bandura, "among the types of thoughts that affect action, none is more central or pervasive than people's judgements of their capabilities to deal effectively with different realities" (1986, p. 21). Numerous quantitative studies in the last thirty years have correlated high TSE beliefs with teacher behaviour associated with success, such as greater effort and persistence, and with positive learning outcomes (Tschannen-Moran \& Woolfolk-Hoy, 2007).

Low TSE beliefs, in contrast, are thought to have a damaging effect on behaviour and other cognitions when experienced across a range of teaching tasks. Yet, doubting one's efficacy is regarded as essential for learning (Wheatley, 2002) and there is evidence that TSE can be positively impacted 
through teacher education activities that encourage reflective thought (Henson, 2001). Through reflection, Bandura (1986) argues, teachers can make use of various sources of efficacy-building information, including 'mastery' experiences of succeeding in similar tasks. These experiences stimulate knowledge growth and more positive TSE beliefs (Fives \& Alexander, 2004).

The knowledge most relevant to teacher is practical, "as much of what teachers know originates in practice and is used to make sense of and deal with practical problems" (Elbaz, 1981, cited by Borg, 2006, p. 13). Practical knowledge is thus "directly related to action ... readily accessible and applicable to coping with real-life situations" (Calderhead, 1988, p. 54). Informed by formal knowledge, it is also personal, tacit, systematic and dynamic, continually refined by educational and professional experiences (Borg, 2006). Various dimensions of practical knowledge include the self, milieu, subject matter, curriculum and instruction (Elbaz, 1981), categories I have modified slightly, on the basis of research with English language teachers, to include: the learners and learning, the curriculum, teaching techniques, the school context and the self (Wyatt, 2009b), categories I use here. In this paper, in exploring dimensions of an English teacher's practical knowledge and TSE growth during an in-service BA TESOL, I focus specifically on his use of groupwork with young learners. This is a qualitative case study.

\section{Investigating TSE from a qualitative perspective}

While studies of teachers' developing practical knowledge have made use of longitudinal, qualitative case studies since the work of Elbaz (1981) and Clandinin \& Connolly (1986), such methodology has been neglected in the field of TSE research, as Tschannen-Moran, Woolfolk-Hoy \& Hoy (1998) report. Indeed, only in the last decade have such studies started to emerge. Yet, as qualitative research produced by Milner \& Woolfolk-Hoy (2003), Mulholland \& Wallace (2001) and Rushton (2003) demonstrates, such methodology is valuable in various ways, particularly since TSE is task- and context-specific (Bandura, 1997), and thus open to exploration through case studies that explore the particularities of experience (Stake, 1995). As argued elsewhere (Wyatt, in press), qualitative case study methodology allows the reader to identify the context-specific tasks teachers set themselves and provides insights into the processes of developing TSE, as efficacy-building experiences, mediated by reflection, contribute to the development of practical knowledge and TSE beliefs. Through triangulation; e.g.; of interview and observational data, qualitative research can also help uncover the foundation of TSE beliefs: To what extent is there synergy between reported beliefs and observed behaviour?

Of the studies referred to above, several (Rushton, 2003; Wyatt, in press) address the relationship between practical knowledge and TSE. In neither, though, is there a systematic focus on how dimensions of practical knowledge 
develop in relation to TSE with regard to any particular task, such as using groupwork to support learning in a particular context. In this respect, the current study makes a distinctive contribution.

\section{Groupwork in language teaching}

As Moon (2000) explains, most modern coursebooks designed for English as a second language classrooms advise teachers to use groupwork "because of the opportunities this offers for increased language input, pupil practice and greater involvement in language learning. Children are, by nature, very sociable and groupwork makes use of this natural tendency" (p. 53). Such advice is underpinned by an interactionist view of second language acquisition. In particular, Vygotsky's (1962) "notion of the zone of proximal development [ZPD], the level of performance which a learner is capable of when there is support from interaction with a more advanced interlocutor" (Lightbown \& Spada, 1999, p. 44), has been very influential. Various researchers (e.g. Ellis, 2003; Gillies, 2003) have highlighted the cognitive, metacognitive, affective, social and linguistic benefits of groupwork for young learners.

Such benefits can be realized in the classroom if certain principles apply. Firstly, activities are required that are both intrinsically motivating and encourage meaningful interaction as learners work towards clear aims. Secondly, if learners are to be active it is important that all are involved, which can be achieved both through task design (e.g. the use of information gaps) and group organization, with learners given different roles; e.g. facilitator, time keeper, language leader, reporter (Abdullah \& Jacobs, 2004). Thirdly, group composition needs to reflect the goals of the activity. While mixed ability groups allow high achievers to support and scaffold the work of low attainers in a Vygostskyan way (Saleh, Lazonder \& de Jong, 2007), sometimes letting learners form their own groups, based on friendship, might be appropriate (Moon, 2000).

Other factors that influence the success of groupwork include classroom management issues, such as orientating learners towards groupwork, providing clear instructions, careful monitoring (e.g. for on-task, passive or dominating behaviour) and focused feedback. Organizing the seating in an appropriate way may also help the teacher create positive group dynamics (Dörnyei \& Malderez, 1997). A teacher's personal skills and qualities are also important, including reflective skills for the fine-tuning of groupwork activities and persuasive skills to encourage positive attitudes in the school towards groupwork, e.g. attitudes that are accepting of the noise that groupwork can generate.

It can be seen from the above that practical knowledge of various kinds (relating to the learners and learning, the curriculum, teaching techniques, the school context and the self) might be required of teachers if they are to use 
groupwork successfully and efficaciously to support learning. However, this is an area in which only limited research has been conducted, though Mulholland \& Wallace (2001) followed the efforts to use groupwork of a beginning science teacher in Australia: Katie, as is common with many beginning teachers, struggled with classroom management issues before her TSE improved. In this research, I focus on a teacher of English (rather than Science) at a rather different stage of his development (on an in-service BA TESOL) and working in a different context (the Middle East). I describe this context below.

\section{The research context}

The three-year in-service BA TESOL was conducted by the University of Leeds for the Ministry of Education in the Sultanate of Oman. The programme, designed to upgrade the qualifications of Diploma-holding teachers, offered modules related to ELT methodology, second language acquisition, language awareness and research methods. Participants studied intensively during summer and winter, and then attended day release throughout the rest of the year, when they had an opportunity to put ideas picked up on the course into practice, as they were also teaching. Once a semester, they were observed in their schools by a regional tutor, who used feedback sessions to help them relate theory to practice. Teaching practice was not assessed.

The BA programme was part of a large-scale educational reform project, focused on curriculum renewal. Indeed, just before joining the course, the research participant, Rashid (pseudonym used) had transferred to a new school (where he would teach Grade 5-6 eleven-twelve year-old boys) and use groupwork for the first time. His own education had been in teacher-fronted classrooms, with the learners sitting in rows, and his 8-years teaching experience had predominantly been in the same mode.

Various criteria used by Dangel \& Guyton (2004) to identify constructivism in teacher education are evident in the BA programme design. Instruction was participant-centred, with regular opportunities for task-based, analytical and interactive work. Awareness-raising activities that invited a re-examining of beliefs and practices were also present. Use was made of input in the form of readings, videos of classroom practice, role-plays and scenarios of classroom situations to prompt teachers to engage with theoretical material and to connect this with their own views and experiences. Assignments involved them in conducting action research.

Modules of particular relevance to Rashid's concern with using groupwork to support learning included several in the first year, including 'Teaching English to Young Learners' (TEYL) and 'Language Acquisition and Learning' (LAL). Then, in the second year, the module 'Researching TESOL' led into action research for his 'Dissertation' in the final year, which he focused on his 
own use of groupwork (for an in-depth account of the BA TESOL and its context, see Atkins, Lamb \& Wedell, 2009).

\section{Research methodology}

My research questions are as follows: In the context of a three-year in-service BA TESOL:

1. Which dimensions of a teacher's practical knowledge, regarding the learners and learning, the curriculum, teaching techniques, the self and the school context, appeared to develop most?

2. To what extent did growth in his self-efficacy in using groupwork with young learners appear to mirror growth in his practical knowledge?

3. What might explain the various changes?

The research was part of a larger study (Wyatt, 2008), which examined the development of five teachers throughout their three-year course, focusing on growth in practical knowledge and self-efficacy in relation to different topics that emerged (e.g.; one case focused on developing reading skills, another on materials design) (see Wyatt, 2009a; 2010; for several of the resulting stories). Returning to the focus of this paper, Rashid identified the use of groupwork to support learning as a particular interest in early interviews, and sustained this interest throughout the course. By aligning my research interests in his developing TSE to this context-specific task, I aimed for ecological validity (Cohen, Manion \& Morrison, 2000).

This was insider research, in that I was involved, as a teacher educator, in developing the qualities I was investigating, which suggests links to critical theory and to Holliday's (2002) progressive qualitative paradigm. However, this can also be seen as interpretive case study research (Stake, 2000). My own role as an 'agent of change' (Kennedy, 1996) was relatively minor in that, while I could and did encourage Rashid to learn and persevere as his regional tutor, I had no influence on his teaching context. Rashid was a volunteer, who signed an informed consent form which promised anonymity and the right to withdraw at any time. Strict ethical guidelines were followed.

In producing a longitudinal, qualitative case study, I have drawn chiefly on several methods; semi-structured interviews (Kvale, 1996), observations, in which my own role was as a 'non-participant observer' (Cohen et al., 2000), and the analysis of Rashid's written assignments, which can be seen as a form of reflective writing (Borg, 2006), in that they included reflections, though they need to be treated cautiously as they were written with a view to pleasing a discourse community of markers. Using this combination of methods, which I have discussed at length elsewhere (Wyatt, 2008; 2009a; 2010) allowed me to triangulate reported cognitions with observed behaviour (Borg, 2006), and thus assess the extent to which declared beliefs seemed based on reality, which was key to addressing research questions. My analytical procedures were 'interactive' and 'iterative' (Calderhead \& 
Shorrock, 1997), involving transcription and the use of a 'template approach' (Robson, 2002) to data analysis to facilitate the move from coding to interpretation (Coffey \& Atkinson, 1996).

I now present a narrative account of Rashid's experiences, using 'thick description' (Geertz, 1973) and drawing primarily upon the following sources of interconnected data (Holliday, 2002): six observations; eight interviews including 1 for member checking (Stake, 1995); and three assignments, together with feedback on these (see Appendix 1 for details). Data referred to are coded as follows (after Borg, 1998):

\begin{tabular}{|l|l|l|}
\hline Teacher's pseudonym & Source of data & Number \\
\hline Rashid - S & $\begin{array}{l}\text { Assignment - A } \\
\text { Feedback - F } \\
\text { Interview - I } \\
\text { Observation - O }\end{array}$ & $1-8$ \\
\hline
\end{tabular}

\section{Results}

\subsection{His first research into groupwork}

Rashid first researched his use of groupwork for his LAL assignment (October - December 2003), when required to keep a reflective journal focused on language acquisition issues. In successive weeks, he recorded problems with groupwork in his classes. First, he focused on the issue of stronger students grouping themselves together, leaving lower ability students consequently lacking support, to which he responded by introducing mixed ability groupings. In subsequent weeks, he interviewed students for their reported groupwork behaviour (considering the ZPD), compared the outcomes of groupwork and individual work, examined the effects of introducing a competitive element to groupwork activities (considering extrinsic and intrinsic motivation) and addressed the issue of group domination by a student in one of his classes: his solution was to assign specific roles (RA.1). Feedback on the journal, marked in Leeds, mentioned the connections Rashid made between practice and theory (RF.1), and I discuss these connections below, triangulating Rashid's written words (RA.1) with observational and interview data, to explore his practical knowledge.

I observed a lesson at the start of the week when he re-divided the students into mixed ability groups, focusing on levels of participation and involvement, concentrating on the behaviour of a few learners who caught my attention (RO.2). Rashid judged the re-grouping ' $40 \%$ successful'. The strong students, who had been in one group before, had done as he asked and tried, in the new groups, to encourage others "to cooperate with them", but many, particularly those not sitting adjacent to the strongest student in each group of six, had not done so, preferring to stay passive. I shared my observation that one boy, in particular, had seemed distracted. Rashid explained that all the 
strong students had been from his group, and, over-reliant on their help, he was missing them; in time, he would become more independent (RI.1).

After this lesson, Rashid persevered with the new grouping arrangements and recorded progress in the way the groups interacted with the newly appointed leaders. A week later, he sought evidence of improved learning from their workbooks; this showed "they answered the comprehension questions as required in the activity" (RA.1).

In demonstrating observational skills and the ability to use evidence to judge learning outcomes, I felt Rashid was demonstrating practical knowledge in both using groupwork and doing classroom research, though interestingly soon afterwards he told me he did not "really know how to conduct research" (RI.2). This suggests that, for his TSE to develop, perhaps he needed a deeper practical understanding of the term 'research', one he could gain through further 'mastery' experiences (Bandura, 1986).

\subsection{Rashid's developing understanding of learning processes}

Much of the input Rashid received through LAL in 2003 was completely new, "like Krashen's theories and hypotheses". Other theories contradicted those he had learned ten years earlier on his initial teacher training diploma. It was a bit "challenging", as he tried to "understand and compare and remove the old ideas" (RI.2). One of these ideas was faith in the value of giving gifts, prizes, which, Rashid argued in his LAL journal, would not support learning. "They will learn for the gifts, which causes extrinsic motivation. I remember one day", he continued, "when my tutor [advised] me to avoid rewarding pupils ... during his first school visit to me" (RA.1). This had been in March 2003, in the first semester of the BA Programme. I had recommended praising groups for working cooperatively towards a purpose rather than singling out individuals for prizes, particularly with rewards like chocolates, and had mentioned Skinner's M\&M theory (Brown, 1990) (RO.1).

Prior to the BA course, Rashid “didn't know about the ZPD" (RI.2). Learning about this theory helped him as a teacher, he reported. "I used to believe that my learners cannot depend on themselves in learning [or] learn from each other", he wrote in his journal (RA.1). "I wasn't understanding my students", he told me, "what they need, what they have, but now I can understand what they know and what they should know", and he felt he could build on this. "They have some knowledge, they have got ZPD. I should complete, just complete, not restart or start from the beginning" (RI.2). One of the students he interviewed for his LAL journal told him "that sometimes he has part of an answer, but for some reason (shyness, confusion, worry), cannot say it to the teacher. He finds that in groupwork he can share his answer with the [group leader]". Rashid saw this as evidence that the ZPD could lead to further acquisition and learning (RA.1). 
The awareness of having a clearer insight into children's minds seemed to have empowered Rashid. "I can manage psychological problems", he told me, with quiet self-confidence, "and their weaknesses and their needs also. I can understand what they need and what they lack" (RI.2). Theoretical knowledge, relating to the ZPD, had been assimilated into his practical knowledge, and Rashid seemed more efficacious about solving learners' problems through groupwork.

\subsection{A groupwork activity from the coursebook}

One LAL journal entry concerned group domination by a strong student, a problem which Rashid responded to by assigning roles to encourage a sharing of responsibilities (RA.1). The marker suggested he should change the nature of the task: "if you make it information gap then everyone has to speak!" (RF.1). Issues of group domination and how to address this problem were relevant to the next Grade 5 lesson I observed in Rashid's school, in March 2004. For this, the layout of the classroom was not exactly as he would have liked. The tables were arranged for large groups of up to 8 , as the classroom was shared by other teachers, who had other preferences. Sometimes, as today, Rashid accepted the existing seating arrangements, rather than spend time on reorganization (RO.3, RI.3).

The topic was food, and the first activity was a reading race. Rashid stuck a poster on the whiteboard showing food in a supermarket. In turns within their groups, learners were supposed to run up to the whiteboard, look at the poster, find a food item amongst the fruit, vegetables, drinks and types of meat, make a mental note of the accompanying number and run back to their group to supply this. Another group member should write the information on a checklist. Then someone else should take over: run up, look, read, remember, run back and report (RO.3).

However, although the activity was set up with clear instructions, it quickly unravelled. Many learners went off-task, with only a few involved in each group, monopolizing either the writing or the running and reading. Despite receiving encouragement Rashid offered while monitoring, some groups gave up, discouraged, and in the end none actually completed the task (RO.3). Checking afterwards, Rashid discovered that some groups had only 5 or 10 answers correct, out of 26 (RI.3).

I thought there were various problems with the activity that should have been addressed. Firstly, the physical space could have been better organized. Secondly, more time could have been spent on supporting language demands in the setting up process through an activity that activated or pre-taught vocabulary. This could have helped the learners succeed. As it was, Rashid spent 15 minutes afterwards checking the answers; this included time which could have been re-allocated for preparation. Thirdly, I felt clearer rules and 
more systematic management would have helped reduce the domination of groups by certain individuals (RO.3). What did Rashid think?

"I faced a problem in the reading race," he acknowledged at the start of the post-lesson discussion. The learners did not know or could not remember most of the vocabulary, apart from "common things like bananas or oranges", even though, as Rashid assured me, the vocabulary was being recycled. However, he rejected my suggestion that he could have added a preparation activity. This would have taken 5 minutes, and if he regularly added such activities for recycling, he would not complete the syllabus. This would cause problems, as all the books followed from one another, and there were the progress tests supplied by the administration he had to use. "How then would the learners catch up?" He hoped they would learn indirectly or make active use of the environment. A strategy he had suggested to his classes for the current unit was to look at the English names of food items when they accompanied their parents to the supermarket (RI.3). Such a solution, while admirable, did not strike me as adequate. I felt Rashid was making the mistake of teaching the book not the learners.

Regarding group domination, Rashid felt the cause was the competitive nature of the activity: "They want to win; they've got a desire to play and to win." He had tried to control this: "I didn't allow sometimes ... I gave them [the stronger students] a lot of work, the harder work, which is writing". My response was that language demands might have placed a strain on the functioning of the groups. Even with the stronger students dominating, so few answers were correct, I pointed out (RI.3). My feeling was that, perhaps, if the groups had been smaller, if key vocabulary had been reactivated through a preparation activity, and if the groups had been set goals for cooperation as well as completion, then perhaps they would have done better. In offering this feedback, I tried to be positive. Nevertheless, I was concerned that Rashid's lack of flexibility with the coursebook might inhibit growth in practical knowledge and TSE in using groupwork.

\subsection{Researching groupwork for his Dissertation}

Rashid was aware that he had "some problems with groupwork", he told me the following semester (in October 2004); "sometimes it didn't work", and he was grateful to be encouraged to explore these issues; he had not had such support before. He was glad, too, that, from lectures and seminars on the BA programme, he learned about theories he could "discover practically" for himself in the school (RI.4). In his dissertation, he wanted to focus on improving his use of groupwork, particularly with regard to helping low achievers, who, he defined, as "those who find some difficulties [because of] shyness, lack of knowledge and low motivation". They were often labelled as weak and were neglected (RA.2). 
For his research, Rashid would identify four low achievers in one class, and observe them. How would they respond when working in mixed ability groups, when grouped according to their friendships, when given responsibilities within the group? As well as observing while teaching himself, Rashid would invite two colleagues to watch a series of three lessons (RA.2), focusing on individuals while the learners engaged in various groupwork activities of different types; a reading race and a survey in the first lesson, a card game (Pelmanism) and an acted out song in the second, a game of dominoes and a TPR activity in the third (RA.3).

I observed the second of these three lessons in April 2005, as one of two observers. The first lesson had been disappointing, Rashid later explained in his dissertation. The reading race, in mixed ability groups, had been problematic, as the low achievers found the "competitive game difficult". Participation was "dominated by high achievers" and "low achievers got lost". Rashid criticized himself. "As a teacher, I may have failed to control and manage the game activity carefully to avoid these shortcomings" (RA.3). So, there were similarities with the reading race of a year earlier $(6.3$, above).

The lesson in this sequence I observed was more successful. It seemed well organized (RO.5) and the learners found it "enjoyable" (RI.6). I was asked to focus covertly on two students who joined friendship groups. My notes about one included the following:

As you explained how to play Pelmanism to the whole class, he was looking around, fidgeting, and you called out his name to get his attention. After that, he focused on you, concentrating hard. When the group leader came back to his table to explain the activity, he got close, looking curiously, and then helped arrange the cards. He got very involved in the game when it started, trying to read the cards when it was his turn, leaning forward and, at one point, knocking over a chair in his eagerness to participate. It was clear from his smile that he was happy playing. He responded positively when you came over to help. A minute or two later, he was trying to read his friend's card 'They like riding their bikes' upside down (RO.5).

Afterwards, Rashid reported that the boy tried to participate well. However, due to limited ability in reading, he found it difficult to match sentences and pictures. Without a high achiever near him, he needed to ask the teacher for help, and indeed did so on several occasions. Rashid's observation notes complemented mine, and his analysis, concluding from the evidence that being in a mixed ability group would have better supported this particular learner on this occasion, seemed sensible (RI.6).

Rashid had gained self-efficacy in researching his own practice. "I've learned where to focus on the problems of the pupils and the effects, like participation, motivation", he told me: and I've learned how to investigate these problems and how to find out and how to notice, actually, from the observation while I'm teaching, to be a 
researcher and a teacher at the same time. While I'm teaching I notice several problems with the pupils and I can solve the problem maybe immediately or later if the problems are complicated (RI.6).

When I checked the following semester, Rashid reported that the four learners in his study had subsequently improved. Unfortunately, however, he continued, "some teachers still deal with them as difficult cases. When a teacher puts in his mind that this is a difficult case, it's hopeless... but if you consider that they have to improve and encourage them to improve, then you can succeed" (RI.7). This suggests high self-efficacy for dealing with low achievers, high self-efficacy for projecting positive beliefs. It also alludes, though, to frustrations with his teaching context.

\subsection{Rashid's challenging teaching context}

When I next visited Rashid's school, in September 2005, there were no flying classes (the practice of classes moving from one room to another between lessons, according to the next subject) as in previous years. The new headmaster was trying to make the school "calm, more secure" by keeping the pupils in the same place throughout the school day. "The victims", Rashid felt, would be English teachers, science teachers bringing "chemical materials to class" and teachers of various subjects such as himself wishing to rearrange the groups (RI.7).

"Some groups were poor", he reflected after the Grade 6 lesson I observed that day. I highlighted successes; lively whole class interaction, focused group discussions, but Rashid was dissatisfied. He could not organize the groups as he wished to, and some lacked high achievers. A group close to the door, which I had noted "to be cooperating very well" together (RO.6), contained three high achievers, Rashid reported. In contrast, two groups on his right "didn't do well". He had lost control of them "because sometimes they don't know what to do. They are trying but nobody is there to help them". They did not want to move, as the Arabic teacher had told them to stay where they were. "It's a major problem I'm facing in my class", Rashid continued. "What to do?" Another problem was that different subject teachers appointed different group leaders. At the beginning of the semester, a few weeks earlier, he had tried to form his own groups for every lesson, but gave up because this had taken too long to organize (RI.7).

To be able to use groupwork effectively, Rashid felt he needed to be able to regulate his classroom space. He reported he had a "deep understanding" of groupwork now, of "organizing groups and identifying low achievers and where to put them", so that it was "easy now, with the use of groupwork, to help them improve", but he needed his own classroom to do this successfully (RI.7).

Unfortunately, though, Rashid did not get the flying classes he wanted. Though he tried to convince the headmaster, he went the whole year, as I 
discovered the following summer, with learners sitting mostly where other teachers had put them. Occasionally, he tried to change the groups, but the learners complained: "teacher, teacher, all teachers like us to sit here except you, so what's your problem with us?" They could tell him this in Arabic. Sometimes, he tried to convince them, arguing: "by regrouping you, I can help you learn", but to little avail. He felt in a difficult position, unable to devote 5 minutes at the beginning of every lesson to regrouping the class. He was behind with the syllabus, and lost a unit from the coursebook during the semester as it was (RI.8).

I asked him then, in July 2006, if he felt better able to use groupwork than he had been at the beginning of the research. "Yes", he told me,

but it depends on the conditions. First of all, if I have got some problems, I have to fix the problems, for example, my own teaching room, my techniques, my students and the cooperation of the school, other teachers' cooperation as well. First of all, I have to fix these problems, and then I could work well with groupwork (RI.8).

Rashid seemed realistic about the context. Though he could notice problems, he felt unable to do much about them. This limited practical knowledge and TSE growth. He had gone a whole year hardly able to put his ideas into practice, which must have been frustrating.

\section{Discussion}

I now address research questions.

\subsection{Which dimensions of Rashid's practical knowledge, regarding the learners and learning, the curriculum, teaching techniques, the self and the school context, appeared to develop most?}

It is evident from the narrative above that Rashid developed more in some respects than others. Practical knowledge regarding the learners and learning, and the self, as both teacher and researcher, were areas in which he seemed to grow considerably. From theoretical input focused on the ZPD, Rashid developed a practical understanding of the role of social interaction in learning through experimenting with various types of group organization (including mixed abilities) and analysing the outcomes. Varied experiences, mediated by reflection (6.2, above), thus led to formal knowledge becoming part of his practical knowledge (6.4, above).

However, in certain respects there was less growth. Although learners found a groupwork activity (the reading race) too challenging, Rashid seemed unwilling to add a preparation activity to reduce task demands. In adhering to the syllabus in this way, he emphasized the paramount need to complete the course. This suggests that his practical knowledge in adapting the curriculum to meet local needs remained under-developed. He did not gain the professional experiences (Borg, 2006) that would support such growth. 
Practical knowledge growth regarding teaching techniques was also disappointing. While his classroom management skills seemed adequate for most purposes (unlike those of Katie, the beginning teacher described by Mulholland \& Wallace, 2001), they seemed less so for handling a reading race in an observed lesson, after which he attributed the failure of the activity to the learners' language level (6.3, above). Rashid's reflective writing subsequent to a further reading race suggests, though, he became more aware of the problem as relating to his teaching $(6.4$, above), a reflective insight which would suggest the possibility of growth.

Unfortunately, Rashid found contextual challenges insurmountable. His inability to convince the headmaster to allow flying classes, the reluctance of his students to re-group and his concern about losing time for this, as it would affect curriculum completion, combined to curb his experimentation and inhibit practical knowledge growth.

To summarize, Rashid's practical knowledge, as Elbaz (1981), Calderhead (1988) and Borg (2006) describe this, developed unevenly. Through drawing on educational experiences, reflecting and experimenting in his professional context, he was able to develop in some areas. He gained insights (consistent with Moon, 2000) into the use of groupwork to achieve goals, developing practical knowledge which was enacted in the classroom within constraints partly imposed by the curriculum and the context.

\subsection{To what extent did growth in Rashid's self-efficacy in using groupwork with young learners appear to mirror growth in his practical knowledge?}

As described (in 1) above, TSE beliefs mediate between knowledge and action, influencing the degree of effort put into any given task (Bandura, 1986). Though TSE beliefs may under- or over-estimate (2, above), Rashid's did seem to fit his practical knowledge fairly well.

Rashid became more efficacious, for example, about organizing groupwork in a way that would encourage social interaction and support low achievers. He clearly believed that success in this could be achieved (6.4, above), which accords with the practical knowledge growth described in 7.1 (above). Similarly, while developing practical knowledge in researching his own practice in using groupwork, he became more efficacious in this $(6.4$, above). Earlier, however, he may have under-estimated his strengths in this regard (6.1, above), perhaps as his practical understandings of research may then have been less developed.

Conversely, Rashid's acknowledgement of problems in managing reading races $(6.5$, above) suggests lower TSE in this regard, which again would fit my analysis of his practical knowledge in this area. As argued (in 1) above, such self-efficacy doubts can benefit learning (Wheatley, 2002), but not when they 
persist over time (as appeared to be the case in relation to his inability to handle contextual demands).

Damage to his TSE seems evident in Rashid's description of himself as 'a victim' (6.5, above). His use of the modal 'could' rather than 'can' in the same context was also indicative; if he fixed his problems, he says he 'could' use groupwork effectively, signalling, in this word choice, that the target was unrealistic.

This analysis suggests, therefore, that insights into task-specific TSE can be gained from analysing dimensions of a teacher's practical knowledge. As noted (in 3) above, few studies (Rushton, 2003; Wyatt, in press) have explored these concepts together and not in the same way. The focus of Wyatt (in press), for example, is on the role of reflective actions in helping a teacher overcome low TSE.

The present analysis also demonstrates the need for qualitative research methodology, involving triangulation of methods and the use of discourse analysis techniques, to explore the context-specific nuances of TSE and any apparent discrepancies between this and practical knowledge. Much of the quantitative research surveyed by Tschannen-Moran et al. (1998) assumes that such beliefs are 'accurate'. As suggested here, the picture can be more complex. I now explore underlying reasons for Rashid's development.

\subsection{What might explain the various changes?}

Rashid was motivated to make practical use of ideas related to language acquisition introduced on the BA programme (ideas based on principles outlined, in 3, above), motivated, too, to make groupwork succeed for the young learners in his particular teaching context,. In focusing on these goals, he was helped by constructivist features of the BA course (Dangel \& Guyton, 2004), in particular, teaching while studying part-time, engaging in action research, addressing classroom problems supported by mentoring. These were also features of a teacher education programme described by Henson (2001) that led to positive outcomes in terms of self-efficacy growth. However, Rashid's growth in TSE was constrained by the school environment and administrative requirements; e.g. the need to complete the syllabus. This demonstrates the importance of the context in shaping teachers' cognitions and behaviour (Borg, 2006). Rashid was a caring, sensitive teacher, finally unable to handle contextual challenges.

\section{Conclusions}

In this paper, I have focused on the relationship between dimensions of practical knowledge and TSE growth in a way that has not been attempted before. Such an approach has allowed me to highlight the successes and failings of the particular teacher education programme and isolate continuing educational needs. While Rashid appeared to benefit from the research and 
language acquisition strands of the BA programme, he may have needed more hands-on practice in managing groupwork activities, which suggests more micro-teaching in methodology modules. He also needed space in which to grow, and thus greater flexibility in both the materials he worked with and within the school organization. There is a danger that if management processes for school and curriculum are top-down and restrictive then teachers may find their growth in practical knowledge and TSE stifled, as happened in this particular case.

In exploring these relationships while telling Rashid's story, I have constructed a narrative account of his development using interconnected qualitative data. While examining reported cognitions in relation to observed actions, I have used a variety of clues to piece together understanding, trying to be reflexive at every stage. A limitation of the research is that observational data was limited to six lessons, due to my work schedule, but triangulation with assignments as well as interviews compensated for this to some extent. Research in other contexts, that may uncover different patterns of growth in practical knowledge and TSE, is called for.

\section{References}

Abdullah, M. \& Jacobs, G. (2004). Promoting cooperative learning at primary school. TESL-EJ 7 (4), 1-12.

Atkins, J., Lamb, M. \& Wedell, M. (Eds.). (2009). International collaboration for educational change: The BA project. Muscat: Ministry of Education, Sultanate of Oman. Retrieved 19 August 2010 from the website: http://www.moe.gov.om/Portal/sitebuilder/Sites/EPS/english/IPS/I mporta/tesol/4/4.aspx

Bandura, A. (1977). Self-efficacy: Toward a unifying theory of behavioural change. Psychological Review 84, 191-215.

Bandura, A. (1986). Social foundations of thought and action: A social cognitive theory. New York: Prentice-Hall. Retrieved 23 November 2003 from Emory University website: www.emory.edu/EDUCATION/mfp/effpassages

Bandura, A. (1997). Self-efficacy: The exercise of control. New York: Freeman.

Borg, S. (1998). Teachers' pedagogical systems and grammar teaching: A qualitative study. TESOL Quarterly 31 (1), 9-38.

Borg, S. (2006). Teacher cognition and language education: Research and practice. London: Continuum.

Brown, H.D. (1990). M \& Ms for language classrooms? Another look at motivation. In J.E. Alatis. (Ed.), Georgetown University Round Table on Languages and Linguistics. Washington, DC: Georgetown University Press.

Calderhead, J. (1988). The development of knowledge structures in learning to teach. In J. Calderhead (Ed.), Teachers' professional learning (pp. 51-64). London: The Falmer Press.

Calderhead, J. \& Shorrock, S. (1997). Understanding teacher education: case studies in the professional development of beginning teachers. London: Falmer. 
Clandinin, J.D. \& Connelly, M.F. (1986). Rhythms in teaching: The narrative study of teachers' personal practical knowledge in classrooms. Teaching and Teacher Education 2 (4), 377-387.

Coffey, A. \& Atkinson, P. (1996). Making sense of qualitative data: Complementary research strategies. Thousand Oaks, California: Sage.

Cohen, L., Manion, L. \& Morrison, K. (2000). Research methods in education (5 ed.). London: RoutledgeFalmer.

Dangel, J.R. \& Guyton, E. (2004). An emerging picture of constructivist teacher education. The constructivist 15 (1), 1-35.

Dörnyei, Z. \& Malderez, A. (1997). Group dynamics and foreign language teaching. System 25 (1), 65-81.

Elbaz, F. (1981). The teacher's 'practical knowledge': A report of a case study. Curriculum Inquiry 11, 43-71.

Ellis, R. (2003). Task-based language learning and teaching. Oxford: OUP.

Fives, H. \& Alexander, P.A. (2004). Modelling teachers' efficacy, knowledge, and pedagogical beliefs. Paper presented at the annual meeting of the American Psychological Association, Honolulu. Retrieved 28 January 2007 from the website: www6.tltc.ttu.edu/hfives/Fives\&Alexander.APA

Geertz, C. (1973). The interpretation of cultures: Selected essays. New York: Basic Books.

Gillies, R.M. (2003). Structuring cooperative groupwork in classrooms. International Journal of Educational Research 39, 35-49.

Henson, R.K. (2001). The effects of participation in teacher research on teacher efficacy. Teaching and Teacher Education 17 (7), 819-836.

Holliday, A. (2002). Doing and writing qualitative research. London: Sage.

Kennedy, D. (1996). The role of the foreign teacher as agent of change and implications for teacher education programmes in Chinese teacher training colleges. ELTED 2 (1). Retrieved 28 June 2009 from the website: www.elted.net/issues/volume-2/kennedyd

Kvale, S. (1996). InterViews: An introduction to qualitative research interviewing. Thousand Oaks, California: Sage.

Lightbown, P.M. \& Spada, N. (1999). How languages are learned. ( $2^{\text {nd }}$ ed.). Oxford: OUP.

Milner, H.R. \& Woolfolk-Hoy, A. (2003). A case study of an African American teacher's self-efficacy, stereotype threat, and persistence. Teaching and Teacher Education 19 (2), 263-276.

Moon, J. (2000). Children learning English. Oxford: Macmillan Heinemann.

Mulholland, J. \& Wallace, J. (2001). Teacher induction and elementary science teaching: enhancing self-efficacy. Teaching and Teacher Education 17 (2), 243-261.

Robson, C. (2002). Real world research (2nd ed.). Malden, MA, USA: Blackwell.

Rushton, S.P. (2003). Two preservice teachers' growth in self-efficacy while teaching in an inner-city school. The Urban Review 35 (3), 167-189.

Saleh, M., Lazonder, A.W. \& de Jong, T. (2007). Structuring collaboration in mixed-ability groups to promote verbal interaction, learning and 
motivation of average-ability students. Contemporary Educational Psychology 32, 314-331.

Stake, R.E. (1995). The art of case study research. Thousand Oaks, California: Sage.

Stake, R.E. (2000). Case studies. In N.K. Denzin \& Y.S. Lincoln (Eds.), Handbook of qualitative research (2nd ed.) (435-454). Thousand Oaks, California: Sage.

Tschannen-Moran, M. \& Woolfolk-Hoy, A. (2007). The differential antecedents of self-efficacy beliefs of novice and experienced teachers. Teaching and Teacher Education 23 (6), 944-956.

Tschannen-Moran, M., Woolfolk-Hoy, A. \& Hoy, W.K. (1998). Teacher efficacy: Its meaning and measure. Review of Educational Research 68, 202248.

Vygotsky, L.S. (1962). Thought and language. Cambridge: MIT Press.

Wheatley, K.F. (2002). The potential benefits of teacher efficacy doubts for educational reform. Teaching and Teacher Education 18 (1), 5-22.

Wyatt, M. (2008). Growth in practical knowledge and teachers' self-efficacy during an inservice BA (TESOL) Programme. Unpublished doctoral dissertation. School of Education: University of Leeds, UK.

Wyatt, M. (2009a). Practical knowledge growth in communicative language teaching. TESL-EJ, 13 (2), 1-23.

Wyatt, M. (2009b). Supporting change in teachers' ideas and practices: The influence of the BA Educational Studies (TESOL) on classroom teaching. In J. Atkins, M. Lamb, \& M. Wedell (Eds.), International collaboration for educational change: The BA project (82-94). Muscat: Ministry of Education, Sultanate of Oman.

Wyatt, M. (2010). One teacher's development as a reflective practitioner. Asian EFL Journal, 12 (2), 135-161.

Wyatt, M. (in press). Overcoming low self-efficacy beliefs in teaching English to young learners. International Journal of Qualitative Studies in Education.

Appendix 1:

List of observations and interviews

\begin{tabular}{|l|l|}
\hline Date & Code \\
\hline $3 / 3 / 03$ & RO.1 (Rashid Observation 1$)$ \\
\hline $6 / 10 / 03$ & RO.2, RI.1 (Rashid Interview 1 ) \\
\hline $22 / 11 / 03$ & RI.2 \\
\hline $22 / 3 / 04$ & RO.3, RI.3 \\
\hline $10 / 10 / 04$ & RO.4, RI.4 \\
\hline $6 / 6 / 05$ & RI.5 \\
\hline $17 / 4 / 05$ & RO.5, RI.6 \\
\hline $17 / 9 / 05$ & RO.6, RI.7 \\
\hline $9 / 7 / 06$ & RI.8 \\
\hline
\end{tabular}


List of assignments referred to (and subsequent feedback)

\begin{tabular}{|l|l|l|}
\hline Date & Module & Code \\
\hline $17 / 12 / 03$ & $\begin{array}{l}\text { Language Acquisition and } \\
\text { Learning (LAL) }\end{array}$ & $\begin{array}{l}\text { RA.1 (Rashid } \\
\text { Assignment 1), RF.1 } \\
\text { (Rashid Feedback 1) }\end{array}$ \\
\hline $6 / 11 / 04$ & Researching TESOL & RA.2, RF.2 \\
\hline $5 / 12 / 05$ & Dissertation & RA.3, RF.3 \\
\hline
\end{tabular}

Please cite this article as:

Wyatt, M. (2010). An English teacher's developing self-efficacy beliefs in using groupwork. System 38 (4), 603-613.

http://www.sciencedirect.com/science/article/pii/S0346251X1000112 $\underline{0}$ 